\title{
Effect Of Exposure Of Monosadium Glutamate (MSG) on Viability Of Monocyte Cells
}

\author{
Aliza Dewi Fortuna ${ }^{1 *}$, Suhariyadi ${ }^{1}$, Evy Diah Woelansari $^{1}$, Purwati $^{2}$ \\ ${ }^{1}$ Medical Laboratory Technology Studies, Health Polytechnic of the Ministry of Health Surabaya \\ ${ }^{2}$ Stem Cell Research and Development Center, Airlangga University \\ *Corresponding author: dewi12311@gmail.com
}

\begin{abstract}
The consumption rate of Monosodium Glutamate (MSG) in Indonesia has increased every year. Uncontrolled use of MSG in Indonesia for a long period of time can cause toxic effects on the body. The free glutamate content produced by MSG can affect the work of the immune system, especially in the innate immune system and cause oxidative stress. To determine the effect of exposure to Monosodium Glutamate (MSG) on the viability of monocyte cells. This study is a laboratory experimental in vitro with a post test only control group design. A total of $10 \mathrm{cc}$ of peripheral venous blood was isolated using the ficoll gradient centrifugation method. The results of monocyte cell isolates were exposed to Monosodium Glutamate (MSG) according to groups. Group I: negative control, group II: monocyte cells + MSG 3\%, group III: monocyte cells + MSG 6\%, group IV: monocyte cells + MSG 9\%. Subsequently incubated for 24 hours at $37{ }^{\circ} \mathrm{C}$ in $5 \% \mathrm{CO}_{2}$. Then the viability test was carried out using trypan blue staining. Monocyte cell viability calculations were carried out under an inverted microscope with a magnification of 400x per 100 cells. The data obtained were analyzed statistically using the one-way Anova test followed by the LSD test. The average viability in each group was obtained as follows, monocyte cell viability in the control group was $63 \%$, group II was $47 \%$, group III was $45 \%$ and group IV was $35 \%$. There is an effect of exposure to Monosodium Glutamate (MSG) on the viability of monocyte cells with the most significant effect being the $9 \%$ MSG concentration with an average viability of $35 \%$.
\end{abstract}

\section{Keywords: Monosodium Glutamate (MSG); viability; monocytes}

\section{INTRODUCTION}

Fast food contains additives that can provide a delicious taste and increase appetite, namely food flavoring or better known as Monosodium Glutamate (MSG). MSG is a sodium salt of one of several non-essential amino acids, namely glutamic acid. This substance functions as a flavoring or flavor enhancer when added to food, is in the form of white crystals and is stable, but can be degraded by strong oxidizing agents. As many as $78 \%$ of the components that make up MSG are glutamate, $12 \%$ sodium and $10 \%$ water. When dissolved in water or saliva, MSG breaks down into free salts and becomes the anionic form of glutamate. The presence of glutamate can open $\mathrm{Ca}^{2+}$ ion channels in neurons that have taste bud receptors so that $\mathrm{Ca}^{2+}$ experiences movement in cells which results in 
receptor depolarization and action potentials, when it reaches the brain it is interpreted as an umami (delicious) taste(Iswara \& Yonata, 2016).

The process of making MSG in Indonesia is carried out by fermentation with the help of the bacteria Micrococcus glutamaicus from molasses (molasses). The number of MSG consumption in Indonesia increases every year, this is indicated by the total production of MSG in Indonesia which reaches 254,900 tons per year with an average consumption of up to $24.1 \%$ per year("Potret Sehat Indonesia Dari Riskesdas," 2018). The threshold value of ADI (Acceptable daily intake) which has been determined by the World Health Organization (WHO) and the Food Additive Organization (FAO) is $120 \mathrm{mg} / \mathrm{kg}$ body weight/day(Munasiah, 2020). Meanwhile, based on the rules of the Ministry of Health, the use of MSG is a maximum of 1-2 teaspoons / day, in 1 teaspoon it is equivalent to 4-6 grams("Potret Sehat Indonesia Dari Riskesdas," 2018). The average number of MSG consumption per day in Indonesia is $0.6 \mathrm{~g} / \mathrm{day}$ into doubt because there is no definite labeling regarding the content of MSG in food, especially in food purchased from outside such as soupy food, causing its use not to be realized by consumers. This condition is exacerbated by the consumption of MSG almost every day(Budiman, 2015).

According to research by (Kazmi et al., 2017) excessive MSG consumption can cause necrosis in hypothalamic neurons, hypothalamic arcuate nuclei, obesity, decreased motor activity and growth hormone secretion, so that MSG has a toxic effect on humans and experimental animals.

Consumption of MSG will produce free glutamate which can activate glutamate receptors in excess so that a small portion is bound to the intestine and most of it is released into the blood. This free glutamate can cause an increase in plasma glutamate levels which are then circulated throughout the body and crosses the blood-brain barrier. In the brain there is a blood barrier in the form of Monocytes then differentiate into macrophages, one of which is microglia which are mononuclear phagocytes in the CNS. Has a variety of cellular functions, such as immune response to injury and infection, cleaning debris at synapses and carrying out homeostatic functions(Pimenova et al., 2017). Macrophages produce prostaglandins (PGE) through the activity of the cyclooxygenase (COX) enzyme. PGE triggers macrophages to increase Nitric Oxide (NO) production, resulting in excess NO production. Excessive NO production can affect monocyte cell viability because the continuous NO exposure causes damage to monocyte cell membranes, causing low cell viability(ElShobaki et al., 2017).

Based on the above explanation, uncontrolled use of MSG in Indonesia in the long term can cause toxic effects for the body due to the accumulation of glutamate so that it affects the work of the immune system, especially the innate immune system and causes oxidative stress. This is the background for researchers to conduct research on the effect of exposure to MSG on monocyte cell viability in vitro. 


\section{METHODS}

This research is an experimental in vitro laboratory with Post test only control group design, which is to measure the treatment group and then compare it with the control group. This research was conducted at the Research and Development Center for Stem Cells, Universitas Airlanga in January - May 2021. The test material for this research was peripheral venous blood of regular D4 students of 2017 majoring in TLM with the inclusion criteria of not smoking, not having systemic diseases and blood disorders, and had signed the informed consent and met the ethical eligibility requirements for this study.

A total of $10 \mathrm{cc}$ of peripheral venous blood was isolated using the Ficoll gradient centrifugation method. The results of monocyte cell isolates were exposed to Monosodium Glutamate (MSG) according to groups. Group I: negative control, group II: monocyte cells $+3 \%$

\section{RESULTS}

The results of the isolation process of monocyte cells in this study were in the form of monocyte cell isolates with the number of cells as much as $5.1 \times 106$ cells $/ \mathrm{mL}$. In the process of isolation of monocytes, four layers are formed,
MSG, group III: monocyte cells + 6\% MSG, group IV: monocyte cells + MSG 9\%. Then it was incubated for 24 hours at $37^{\circ} \mathrm{C}$ in $5 \% \mathrm{CO}_{2}$. Then the viability test was carried out using trypan blue staining. The calculation of monocyte cell viability is carried out below inverted microscope with a magnification of $400 x$ per 100 cells.

The data obtained were analyzed statistically using the Kolmogorov-Smirnov test, namely the normality test and the homogeneity test using the Levene test. If the data obtained are normally distributed and homogeneous, then the One Way ANOVA test is carried out. If there is a significant difference, then it is continued with the LSD test to find out the difference between each group. This research has fulfilled the ethical eligibility requirements issued by the Health Research Ethics Commission of the Health Poltekkes Ministry of Health Surabaya No.EA/455/KEPK-Polltekkes_Sby/V/2021

namely plasma, monocyte cells, ficoll hypaque, and red blood cells. Morphological features of monocytes are round like balls and single-celled as shown by the following figure: 
a)

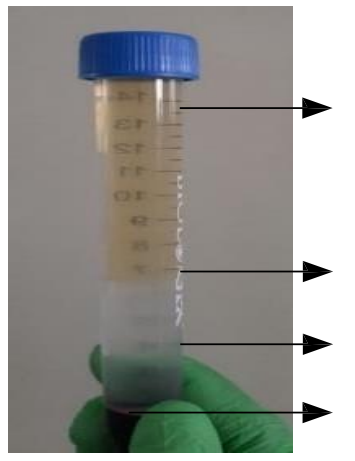

Plasma

Monosit

Ficoll hypague

Red blood cells b)

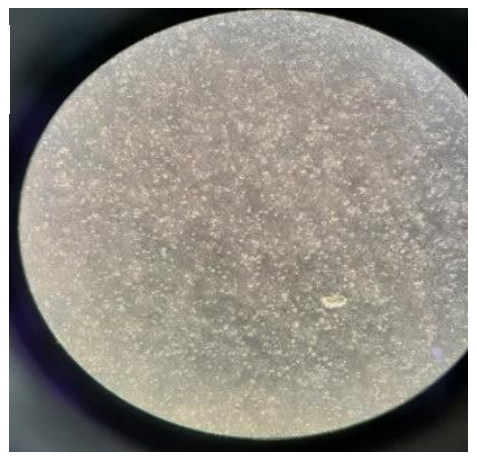

Picture 1. (a) Isolation of monocyte cells (b) Observation of monocyte cell isolates with 100x magnification under an inverted microscope. As a result of the isolation of monocytes, four layers are formed, namely plasma, monocyte cells, ficoll hypaque, and red blood cells

Table 1. Results of Calculation of Viability of Monocytes Exposed to Monosodium Glutamate (MSG)

\begin{tabular}{ccccc}
$\begin{array}{c}\text { Replication } \\
\text { Concentration }\end{array}$ & Cell Control & & Concentratio & Concentratio \\
1 & $70 \%$ & $12 \%$ & $\mathbf{n}$ & $\mathbf{n}$ \\
2 & $50 \%$ & $50 \%$ & $63 \%$ & $30 \%$ \\
3 & $53 \%$ & $50 \%$ & $39 \%$ & $35 \%$ \\
4 & $76 \%$ & $74 \%$ & $45 \%$ & $47 \%$ \\
5 & $36 \%$ & $44 \%$ & $48 \%$ & $23 \%$ \\
6 & $93 \%$ & $54 \%$ & $46 \%$ & $38 \%$ \\
\hline $\bar{X} \pm$ SD & $63 \% \square 21 \%$ & $47 \% \square 20 \%$ & $45 \% \square 11 \%$ & $35 \% \square 8 \%$ \\
\hline
\end{tabular}

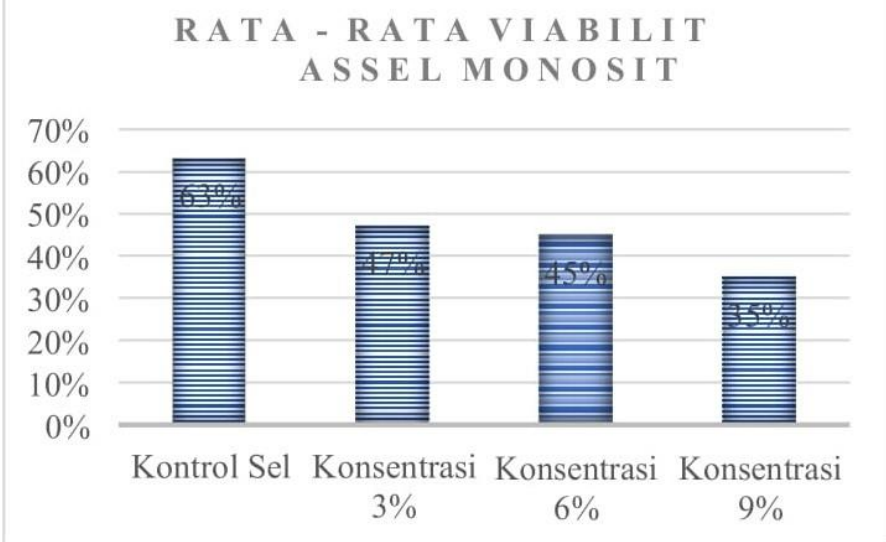

Picture 2. Bar chart of Monocyte Cell Viability exposed to Monosodium Glutamate (MSG).

Based on Table 1, it can be seen that the order of the number of viable (viable) monocytes from lowest to highest was monocyte cells exposed to MSG with a concentration of $9 \%, 6 \%$ concentration, $3 \%$ concentration, and control cells. The monocyte cells that had the lowest 
Viability were monocyte cells exposed to MSG with a concentration of $9 \%$ which was indicated by an average viability value of $35 \%$. Meanwhile, the monocyte cells that had the

\section{STATISTICAL ANALYSIS RESULTS}

Based on the results of the study, the data obtained were analyzed statistically using the One Way ANOVA test as follows.

The results obtained in the one-way ANOVA test are 0.047 with the interpretation that the value if $\mathrm{p}$ value $>0.05$ then $\mathrm{Ho}$ is accepted. Meanwhile, if the $p$ value $<0.05$ then Ho is rejected. Based on the above results, Ho is rejected, which means that there is a significant effect of MSG exposure on monocyte cell viability. highest viability were control cells, which was indicated by an average viability value of $63 \%$ (picture 2).

Table 2. One-way ANOVA test results

\begin{tabular}{|l|r|r|r|r|r|}
\hline \multicolumn{5}{|c|}{ Viabilitas } \\
\hline & Sum of Squares & \multicolumn{1}{c|}{ df } & \multicolumn{1}{c|}{$\begin{array}{c}\text { Mean } \\
\text { Square }\end{array}$} & \multicolumn{1}{c|}{ F } & \multicolumn{1}{c|}{ Sig } \\
\hline Between Groups & 2416,5 & 3 & 805,5 & 3,16 & 0,047 \\
Within Groups & & 5097,333 & & 20 & 254,867 \\
Total & & 7513,833 & & 23 & \\
\hline
\end{tabular}

Table 3. Least Significant Difference (LSD) test results

\begin{tabular}{ccccc}
\hline Kelompok & $\begin{array}{c}\text { Kontrol } \\
\text { Sel }\end{array}$ & $\begin{array}{c}\text { Konsentrasi } \\
\text { MSG 3\% }\end{array}$ & $\begin{array}{c}\text { Konsentrasi } \\
\text { MSG 6\% }\end{array}$ & $\begin{array}{c}\text { Konsentrasi } \\
\text { MSG 9\% }\end{array}$ \\
\hline Kontrol Sel & & 0,105 & 0,065 & $0,006^{*}$ \\
\hline Konsentrasi MSG 3\% & 0,105 & & 0,803 & 0,196 \\
\hline Konsentrasi MSG 6\% & 0,065 & 0,803 & & 0,291 \\
\hline Konsentrasi MSG 9\% & $0,006^{*}$ & 0,196 & 0,291 & \\
\hline
\end{tabular}

Based on the results of the LSD test in table 5.5 , the values that have a significant difference are the viability of monocyte cells in the control group against the MSG treatment group with a concentration of $9 \%$. This is indicated by the obtained value of 0.006 which means $\mathrm{p}<0.05$. While for the other treatment groups there was no significant difference because the $\mathrm{p}$ value $>0.05$. 


\section{DISCUSSION}

The data from the research showed that all cells experienced a decrease in viability, including in group I which was the control group. The decrease in viability in the control group could be caused by several factors including gender and age. Therefore, each individual has a different number of monocytes. This is in line with (Astuti, 2017) which proves that with age, there is a lot of decrease in the number of leukocytes in the body. (Nadhira et al., 2018) also stated that age can affect the number of body immune cells. Meanwhile, the effect of cell number on gender according to (Giyartika \& Keman, 2020) is the ratio of the number of leukocyte cells between women and men is 1:3.

The decrease in monocyte cell viability in the treatment group was caused by an increase in the concentration of MSG. MSG exposure within 24 hours in the treatment group resulted in massive influx of intracellular fluid into the cytosol so that cell permeability disrupted its function. The content of free glutamate produced by MSG can activate the glutamate receptor $\mathrm{N}$ methyl-D-aspartate (NMDA), causing excess $\mathrm{Ca}^{2+}$ influx in the cytosol which can activate NO synthase and protein kinase $\mathrm{C}$ to form free radicals that trigger oxidative stress(Muharani, 2016). According to research by(Agverianti et al., 2019) the occurrence of oxidative stress causes lipid peroxidation which has an impact on cell membrane damage that can affect cell structure and function.

Increased influx of $\mathrm{Ca}^{2+}$ in the cytosol causes mitochondrial dysfunction which causes
ATP depletion. This condition results in disruption of the $\mathrm{Na}^{+}-\mathrm{K}^{+}$ion pump so that the ion gradient cannot be maintained. As a result, $\mathrm{Na}^{+}$ ions cannot be released into extra cells which results in accumulation of water in the cytoplasm, resulting in cell injury(Siagian et al., 2014).

At the time of injury, cells will make a molecular signal that is Damage-associated molecular pattern (DAMPs) that cause inflammation of the sterile pathway. DAMPs will be recognized by natural immunity, one of which is monocytes. Monocytes have pattern recognition receptors (PRRs) that are useful for recognizing damage produced by damaged cells (DAMPs)(Zindel \& Kubes, 2020). The interaction of DAMPs with PRRs will activate monocytes causing the release of major proinflammatory cytokines, namely TNF- and IL-1 $\beta$.

Activated monocytes will repair damaged cells, one of which is by phagocytosis. Monocyte phagocytosis is the process of ingesting particles into phagosome vesicles. In the process of phagocytosis, monocytes will produce ROS such as NO (Nitric Oxide). NO is a metabolic product of the phagocytic process that is useful for killing pathogens or antigens, but if the amount of NO production is excessive it will cause damage to the monocyte cell membrane which can lead to a decrease in monocyte cell viability (Budirahardjo, 2019).

The mechanism of decreasing monocyte cell viability is triggered by the formation of free radicals caused by the accumulation of free glutamate. Free glutamate that accumulates at the synapse can cause excitotoxicity events which is 
neuronal death. According to research by (Asti, 2015) cell viability is affected by the occurrence of free radicals that have an impact on cell damage. This is also in line with Azzahra's research (2014) which states that the formation of free radicals can trigger leukocyte cell lysis.

The viability of monocytes is influenced by the monocyte cell membrane which has an important role, including the integrity of a semipermeable membrane that functions in controlling the exchange of molecules from and into for cell life, as well as providing support for the biochemical activities that exist in the cell(Asti, 2015).

Based on the image of the research results, it can be seen which monocyte cells are alive (viable) and dead (non-viable). The living cells of monocytes have a clear cytoplasm, because the living cells' membranes are still intact so that trypan blue dye cannot penetrate them.

\section{CONCLUSION}

There is an effect of monosodium glutamate (MSG) exposure on monocyte cell viability, namely the higher the MSG

\section{REFERENCES}

Agverianti, T., Muhartono, N., \& Berawi. (2019).

Pengaruh Pemberian Ekstrak Etanol Rimpang Lengkuas (Alpinia Galanga) terhadap Gambaran Hispatologi Hepar Mencit (Mus Musculus LO Yang Diinduksi Monosadium Glutamate. 7(2), 7-13.

Asti, S. I. P. (2015). Terhadap Aktivitas Fagositosis Sel Monosit ( Penelitian
Meanwhile, dead cells have a dark stoplasm (blue) because the cell membrane has been damaged so that trypan blue dye can penetrate. Monocytes whose cytoplasm was clear and did not absorb trypan blue staining were counted as living monocytes, while monocyte cells whose cytoplasm was blue and absorbed trypan blue staining were counted as dead cells. This is based on the principle of trypan blue staining, where trypan blue dye is able to penetrate cells that have died, due to changes in cell membrane permeability or damage to cell membrane integrity. Meanwhile, living cells have impermeable membrane properties so that they cannot be penetrated by trypan blue staining (Shokrzadeh \& Modanloo, 2017).

Based on the results of this study, it can be seen that MSG can reduce monocyte cell viability with MSG concentration which has a significant effect on monocyte viability.

concentration, the lower the monocyte cell viability. The most significant effect is the MSG concentration of $9 \%$ with an average viability of $35 \%$.

Eksperimental Laboratoris InVitro). Universitas Jember.

Astuti, E. (2017). Kadar Benzena Di Lingkungan Kerja Dan Jumlah Leukosit Pada Mekanik Bengkel Ahass.

Budiman, J. (2015). Pengaruh Madu Terhadap Gambaran Mikroskopis Testis pada Tikus Wistar Yang Diinduksi Monosadium 
Glutamat. Universitas Diponegoro.

Budirahardjo, R. (2019). Peningkatan Viabilitas Monosit Oleh Biji Kopi Robusta terhadap Streptococcus Mutans. Pedodonsia, 8-11.

El-Shobaki, F. A., Mahmound, M. H., Attia, A. E.-R. M., Refaat, O. G., \& El-Haggar, E. F. (2017). The Effect Of Monosadium Glutamate (MSG) On Brain Tissue, Oxidation State, True Cholinesterase And Possible Protection Against Health Hazards Using Natural Spices. Der Pharma Chemica, 23(8), 44-50.

Giyartika, F., \& Keman, S. (2020). The Differences Of Improving Leukosit In Radiographers At Islamic Hospital Jemursari Surabaya. Jurnal Kesehatan $\begin{array}{lll}\text { Lingkungan. } & \text { 12(2), }\end{array}$ https://doi.org/10.20473/Jkl.V12i2.2020.97 $-106$

Iswara, I., \& Yonata, A. (2016). Efek Toksik Konsumsi Monosadium Toxic Effects Consumption Of Monosadium Glutamate (pp. 100-104).

Kazmi, Z., Fatima, I., Perveen, S., \& Malik, S. (2017). Monosadium Glutamate: Review On Clinical Reports. International Journal Of Food Properties, 20(2). https://doi.org/10.1080/10942912.2017.129 5260.

Muharani, E. (2016). Pengaruh Pemberian Msg (Monosodium Glutamate) Pada Tikus Sprague-Dowley Betina Usia Reproduktif Selama 2 Minggu Terhadap Kadar Enzim Penanda Kerusakan Sel Hati (Ast/Alt). In Institutional Repository Uin Syarif
Hidayatullah Jakarta.

Munasiah, M. (2020). Dampak Pemberian Monosadium Glutamat Terhadap Kesehatan. Jurnal Penelitian Perawat Profesional, $\quad 2, \quad 451-458$. http://jurnal.globalhealthsciencegroup.com/ Index.Php/Jppp/Article/Download/83/65.

Nadhira, M., Puspitasari, R. L., Moegni, K. F., Rosadi, I., \& Rosliana, I. (2018). Profil Peripheral Blood Mononuclear Cells (Pbmc) Pasien Dengan Berbagai Usia Menggunakan Flow Cytometry Di Klinik Hayandra. Jurnal Al-Azhar Indonesia Seri Sains Dan Teknologi, 4(4), 208. https://doi.org/10.36722/Sst.V4i4.312

Pimenova, A., Marcora, E., \& Goate, A. M. (2017). A Tale Of Two Genes: Microglial Apoe And Trem2. Immunity, 47(3), 398400.

https://doi.org/10.1016/J.Immuni.2017.08. 015.

Potret sehat Indonesia dari riskesdas. (2018). Riskesdas, 10-15.

Shokrzadeh, M., \& Modanloo, M. (2017). An Overview Of The Most Common Methods For Assessing Cell Viability. Journal Of Research In Medical And Dental Science, $5(2)$, 33-41. https://doi.org/10.5455/Jrmds.2017526

Siagian, M., Jusuf, A. A., \& Handini, M. (2014). Pengaruh Pajanan Monosodium Glutamat Terhadap Fungsi Dan Gambaran Histologis Ginjal Tikus Serta Perubahannya Pasca Pengehntian Pajanan. J Indon Med Assoc, 64(7). 
Zindel, J., \& Kubes, P. (2020). Damps, Pamps, And Lamps In Immunity And Sterile Inflammation. Annual Review of Pathology: Mechanisms Of Disease. 15(1),
493-518.

https://doi.org/10.1146/AnnurevPathmechd is- $012419-032847$ 